\title{
粉コークスと気体燃料の併用焼結技術における 酸素富化の影響
}

\author{
岩見 友司 ${ }^{1) *} \cdot$ 山本 $\quad$ 哲也 ${ }^{1)} \cdot$ 樋口 隆英 ${ }^{1)} \cdot$ 主代 晃一 ${ }^{1)} \cdot$ 佐藤 $\quad$ 道貴 ${ }^{1)} \cdot$ 大山 $\quad$ 伸幸 ${ }^{1)}$
}

Effect of Oxygen Enrichment on Sintering with Combined Usage of Coke Breeze and Gaseous Fuel

Yuji Imami, Tetsuya Yамамото, Takahide Higuchi, Kouichi Nushiro, Michitaka Sato and Nobuyuki Oyama

Synopsis : The temperature in the sintering bed is preferably maintained between $1200^{\circ} \mathrm{C}$ and $1400^{\circ} \mathrm{C}$ during sintering to produce high strength and reducibility sintered ore. To achieve this condition, the technology of combined usage of coke breeze and gaseous fuel, which is fed properly from the top surface of the sintering bed, was developed. In this paper, the effect of oxygen enrichment with combined usage of coke breeze and gaseous fuel on the heat pattern in sintering bed and cold strength of sintered ore was investigated. The cold strength of sintered ore was improved by the oxygen enrichment in the pot test. Then, the holding time over $1200^{\circ} \mathrm{C}$ during sintering was extended and improvement of strength would be attributed to promotion of the sintering reaction. By the simulation model calculations based on chemical kinetics, it is considered that the further extension of the holding time over $1200^{\circ} \mathrm{C}$ due to oxygen enrichment is caused of an increase in the distance between the combustion points of the coke breeze and gaseous fuel. However, improvement of the cold strength reached saturation over $32 \mathrm{vol} . \%$ of the oxygen concentration in suction air. It is also considered that the excessive increase of the distance between the combustion points of coke breeze and gaseous fuel decreases overlap of respective heat transfer and doesn't contribute to the expansion of holding time over $1200^{\circ} \mathrm{C}$.

Key words : sinter; gaseous fuel; oxygen enrichment; injection; heat pattern; combustion rate.

\section{1. 緒言}

近年，地球環境，特に温室効果ガスである二酸化炭素 $\left(\mathrm{CO}_{2}\right)$ の排出削減が重要な課題となっている。この課題 への対応策として, 製銑工程では, コークス等炭材の使用 量を低減し, $\mathrm{CO}_{2}$ の排出量を削減することが求められてい る。

製銑工程での $\mathrm{CO}_{2}$ 排出量の削減方法の一つとして, 焼結 工程に打ける凝結材の低減が有効である。焼結工程での凝 結材比の低減には焼結歩留の改善が有効であり, そのため には焼結鉱の冷間強度を改善する必要がある。

焼結鉱の強度向上には, 鉱石同士の結合に寄与する融液 量を増すことが望ましい口。焼結の昇温過程における初期 融液は $1200^{\circ} \mathrm{C}$ 付近で生成を開始する。液相焼結が開始する ため, この温度以上に焼結原料を長時間保持することで, 焼結原料を十分に反応溶融させることができる。一方, 焼 結鉱の被還元性改善の観点からは, $\mathrm{FeO}$ の生成を抑制する 目的で，へマタイトの熱解離温度 ${ }^{2}$ である $1400^{\circ} \mathrm{C}$ 以下に焼 結温度を抑えることも必要とされている。したがって, 焼 結ベッド内の温度を $1200^{\circ} \mathrm{C} \sim 1400^{\circ} \mathrm{C}$ に長時間保持し, 液相 焼結を進行させつつ, $\mathrm{FeO}$ の生成を抑制することにより，
被還元性と冷間強度の両立が可能となると考えられる。

著者らは前報 ${ }^{3}$ において, 焼結ベッド上方より, 気体燃 料を添加し, $1200^{\circ} \mathrm{C} \sim 1400^{\circ} \mathrm{C}$ の保持時間の延長を可能とす る粉コークスと気体燃料を併用した焼結技術を報告した。 これは, 粉コークスの燃焼帯よりも上方で気体燃料が燃焼 することにより, コークス燃焼終了後の $1200^{\circ} \mathrm{C}$ 以上の冷却 帯におけるべッド内温度の冷却速度を緩和するものであ る。

粉コークスと気体燃料を併用する焼結技術のさらなる 進歩のため, ここで酸素富化について, 本論文では検討を 行った。焼結に打ける酸素富化に関しては, Sugawaraら ${ }^{4)}$, Cappel and Weisel ${ }^{5)}$, Noda $ら^{6}$, Kang $ら^{7)} に よ り$ 検討が行わ れている。固体炭材の燃焼速度増加の影響が論じられてい るが，固体炭材と気体燃料を併用した焼結条件において， 酸素富化にともなうヒートパターンの変化に関しては十分 な理解が得られていない。気体燃料の燃焼挙動は固体燃料 の燃焼挙動と異なるため重要である。そこで本報告では, ラボスケールでの基礎研究を実施し, 粉コークスと気体燃 料を併用する焼成条件でのヒートパターンに及ぼす酸素富 化の影響について評価を行った。

原著論文: ISIJ Int., Vol.53 (2013), No.9, pp.1633-1641

平成25年6月3日受付 平成 25年9月26日受理 (Received on Jun. 3, 2013 ; Accepted on Sep. 26, 2013; originally published in ISIJ Int., Vol.53, 2013, No.9, pp.1633-1641) 1）JFEスチール (株) スチール研究所 (Steel Research Laboratory, JFE Steel Corporation, 1 kokan-cho Fukuyama Hiroshima 721-8510)

* Corresponding author : E-mail : yu-iwami@jfe-steel.co.jp

DOI : http://dx.doi.org/10.2355/tetsutohagane.100.189 


\section{2. 実験方法}

粉コークスと気体燃料を併用した焼結において酸素富化 に伴うヒートパターンの変化を調査するために, 焼結鍋試 験装置により, 焼結ベッド内の温度測定実験を行った。試 験装置の概略図を Fig.1 に示す。本実験では, 石英ガラス鍋 (300mm $\phi \times 400 \mathrm{~mm}$ 高さ) を使用し，焼結中の燃焼挙動に ついてビデオカメラ撮影による直接観察を行った。また, 赤外線サーモグラフィを用いてベッド内の温度分布を測定 した。さらに，鍋上端から高さ方向に $100 \mathrm{~mm}$ 間隔で 3 本の $\mathrm{R}$ 型熱電対 $(1.6 \mathrm{~mm} \phi \times 200 \mathrm{~mm}$ 長さ) を水平に原料層内に $150 \mathrm{~mm}$ 挿入し，ベッド内部の温度を測定した。熱電対によ るべッド内温度の測定結果から, 各測定点における $1200^{\circ} \mathrm{C}$ 以上の高温保持時間を求めた。

Table 1 に実験に用いた焼結原料の配合割合を示す。 Table 2 に鉱石 $\mathrm{A}$ と鉱石 B の化学組成を示す。南米産の緻密 質鉱石 (鉱石 $\mathrm{A})$ と豪州産の多孔質鉱石（鉱石 B) を使用し た。

石灰石，硅砂，返鉱，および粉コークスは，実機で使用 しているものを採取して用いた。原料の配合比は，返鉱を $20 \mathrm{mass} \%$ で一定とし, 焼結鉱中の $\mathrm{SiO}_{2}$ が $4.8 \mathrm{mass} \%$, 塩基 度 $\left(\mathrm{CaO} / \mathrm{SiO}_{2}\right)$ が 1.9 となるように, 鉱石と石灰石・硅砂の 配合比を調整した。全ての原料をコンクリミキサーに装 入し, $20 \mathrm{rpm}$ で $180 \mathrm{~s}$ 間混合した後, $1 \mathrm{~m} \phi$ ドラムミキサーに て，12rpmで360s 間造粒を行った。床敷鉱の層厚は $20 \mathrm{~mm}$ で一定とし，準備した擬似粒子を試験鍋に装入した（約 $42 \mathrm{~kg} /$ charge)。全水準において, 点火後の吸引圧力は $6.9 \mathrm{kPa}$ で一定とした。

気体燃料として, 気化した液化天然ガスを(以下 $\mathrm{NG：}$ $\mathrm{CH}_{4} / \mathrm{C}_{2} \mathrm{H}_{6} / \mathrm{C}_{3} \mathrm{H}_{8}=89 / 5 / 6$ vol.\%) を使用した。フード内におい て焼結ベッド表面より $400 \mathrm{~mm}$ 上方にノズルを設置し，点火 後 60s から 360s 経過するまで, NGを吹き込んだ。吸引空気 中の NG濃度を所定の濃度に制御した。酸素富化に関して も, $\mathrm{NG}$ と同様に，フード内の別のノズルより純酸素を吹

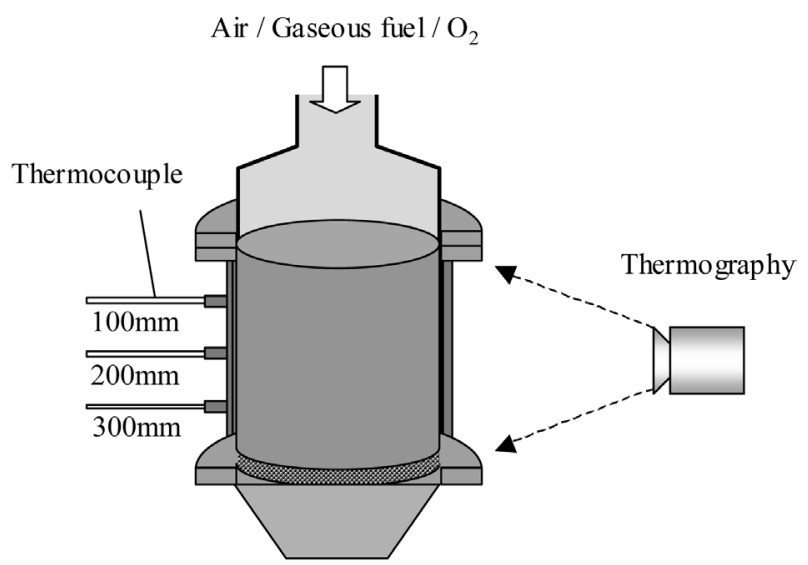

Fig. 1. Measurement method for the temperature in the sintering bed.
き込み, 吸引空気中の酸素濃度を所定の濃度に制御した。

Table 3 に焼結鍋試験の粉コークスと気体燃料, および酸 素富化条件を示す。この試験において, 試験鍋上部からの 吸引空気流量はノズルから $100 \mathrm{~mm}$ 離れた位置のフード上 方配管内に設置されたオリフィス流量計を用いて測定し， 指定した $\mathrm{NG}$ 濃度となるように $\mathrm{NG}$ 流量を調整した。前報 の結果から, NG濃度が可燃限界 $(4.8 \mathrm{vol} . \%)^{8)}$ 以上では, 焼 結べッドに吸引される前に引火することが分かっており， 可燃限界よりも低く設定した。さらに，可燃限界の $10 \%$ 以 上に設定した場合, $\mathrm{NG}$ 添加による改善効果が飽和するた め, NGの濃度は吸引空気に対し，0.4vol.\%に設定した。粉 コークスの配合比は，全原料に対して，5.0 mass\%を基準と した。NG吹き込み条件では，吹き込む $\mathrm{NG}$ と同等の熱量に 相当する粉コークスを削減した。ここで, 粉コークスの燃 焼熱は, 反応による水蒸気の発生は無いものとして, 高位 発熱量の $27.1 \mathrm{MJ} / \mathrm{kg}^{9)}$ を使用し, NGの燃焼熱は, 反応によ る水蒸気の発生を伴い, かつ $100^{\circ} \mathrm{C}$ 以上で水蒸気の凝縮は 無いものとして, 低位発熱量の $41.6 \mathrm{MJ} / \mathrm{Nm}^{3}$ を使用した ${ }^{10)} 。$ 酸素富化する場合に関しては，酸素は単独での燃焼潜熱を 有していないことから，粉コークスの削減は行わなかっ た。大気中の酸素濃度 $21 \mathrm{vol} . \%$ を基準条件として設定し， 酸素富化条件では吸引ガスの酸素濃度を $28 \mathrm{vol} . \%$ として設 定し，オリフィス流量計が示す流量に併せて指定濃度とな るように酸素流量を制御した。

焼結鍋試験後の試料は, $2 \mathrm{~m}$ の高さから 1 回落下させ, $10 \mathrm{~mm}$ 以上の焼結鉱を成品として定義した。ここで, 焼結 歩留は成品焼結鉱の正味重量を, 焼結ケーキの重量で除し て求めた。焼結時間は, 点火から排ガス温度が最高到達温 度に達するまでの時間と定義した。焼結生産率は, 成品焼

Table 1. Blending ratio of sinter mixture used in the experiments.

(mass\%)

\begin{tabular}{c|c}
\hline Blending ore & 66.1 \\
\hline Silica sand & 1.4 \\
\hline Limestone & 12.5 \\
\hline Return fine & 20.0 \\
\hline
\end{tabular}

Table 2. Chemical composition of iron ores.

\begin{tabular}{c|ccccccc}
\hline Material & T.Fe & $\mathrm{FeO}$ & $\mathrm{SiO}_{2}$ & $\mathrm{Al}_{2} \mathrm{O}_{3}$ & $\mathrm{CaO}$ & $\mathrm{MgO}$ & L.O.I. \\
\hline Ore A & 66.14 & 0.07 & 1.26 & 1.31 & 0.03 & 0.06 & 1.41 \\
Ore B & 58.15 & 0.36 & 5.39 & 1.43 & 0.33 & 0.13 & 10.40 \\
\hline
\end{tabular}

Table 3. Experimental conditions in the sintering pot test.

\begin{tabular}{c|cccc}
\hline & Case A & Case B & Case C & Case D \\
\hline Coke (mass\%) & 5.0 & 4.6 & 5.0 & 4.6 \\
$\mathrm{NG}($ vol\%) & 0.0 & 0.4 & 0.0 & 0.4 \\
$\mathrm{O}_{2}($ vol. $\%)$ & 21 & 21 & 28 & 28 \\
\hline
\end{tabular}


結鉱重量と焼結時間から算出した。また，JIS-M8711 (1993) に基づき，落下強度指数（SI）を測定した。

\section{3. 実験結果}

\section{$3 \cdot 1$ ヒートパターンの測定結果}

Fig.2にビデオカメラとサーモグラフィによるべッド内 燃焼挙動の観察結果を示す。ビデオカメラでの観察結果に よれば，酸素富化を行わず粉コークスと NGを併用した条 件 Bでは, 粉コークスのみを用いた条件 Aと比較し, 赤熱 帯の厚みが拡大した。一方, 粉コークスのみを用い, 酸素 富化した条件 Cでは, 条件 $\mathrm{A}$ と比較して赤熱帯の厚みは拡 大しなかった。さらに粉コークスと $\mathrm{NG}$ を併用して, 酸素

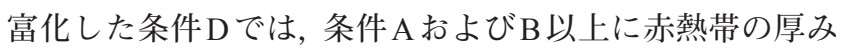
が拡大した。

サーモグラフィのイメージからも同様の傾向を確認す ることができる。サーモグラフィのイメージは側面近傍の

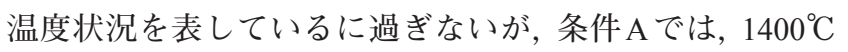
以上の領域が存在するのに対し, 条件 Bでは, $1400^{\circ} \mathrm{C}$ 以上 の領域が存在せず, $1200^{\circ} \mathrm{C}$ 以上の領域が拡大していた。条 件 Dでは, $1400^{\circ} \mathrm{C}$ 以上の領域は条件 B と同様に存在しない が， $1200^{\circ} \mathrm{C}$ 以上の領域が条件 $\mathrm{A}$ および条件 $\mathrm{B}$ 以上に拡大し ている様子が観察された。

Fig.3に, ベッド表面から $100 \mathrm{~mm}$ 地点の温度の測定結果 (ヒートパターン) を示す。ここで横軸は点火からの時間推 移を示している。点火後, 湿潤帯の形成に伴い $100^{\circ} \mathrm{C}$ 未満 の範囲で温度が上昇する。炭材燃焼領域の下降に伴い, 乾 燥帯が測定点を通過する際に急激かつ大幅に温度上昇す る。さらに炭材燃焼発熱量と上部からの吸引空気による冷 却量とのバランスにより最高到達温度に到達し, その後温 度が低下する。
条件 Bでは, 条件 $\mathrm{A}$ とぼ同時に急激な温度上昇を開始 しているが, 最高到達温度からの冷却が緩やかで, $1200^{\circ} \mathrm{C}$ 以上の保持時間が延長した。一方, 条件 Cでは, 急激な温 度上昇の開始時間が条件 $\mathrm{A}$ と比較して早く, 最高到達温度 からの冷却が急であり, $1200^{\circ} \mathrm{C}$ 以上の保持時間が大幅に短 縮された。これは, 酸素富化により粉コークスの燃焼速度 が増加することにより, 燃焼時間が短縮して赤熱帯の厚み が減少し, ここでの圧損が低下し, 吸引差圧一定の条件で は，通過風量が増したためと考えられる。

条件 Dでは, 条件 $\mathrm{A}$ や条件 $\mathrm{B}$ と比較して急激な温度上昇 の開始時間が早く, 最高到達温度からの冷却は条件 $\mathrm{B}$ とほ ぼ同様であった。したがって, 条件Dでは, 条件 $\mathrm{A}$ と比較 して, 急激な温度上昇の開始が早く, 最高到達温度からの 冷却が緩やかであり, $1200^{\circ} \mathrm{C}$ 以上の保持時間が全条件中最 も長くなった。

Fig.4にベッド表面より下方 $100 \mathrm{~mm}, 200 \mathrm{~mm}, 300 \mathrm{~mm}$ の 位置に挿入した熱電対の $1200^{\circ} \mathrm{C}$ 以上の保持時間を示す。条

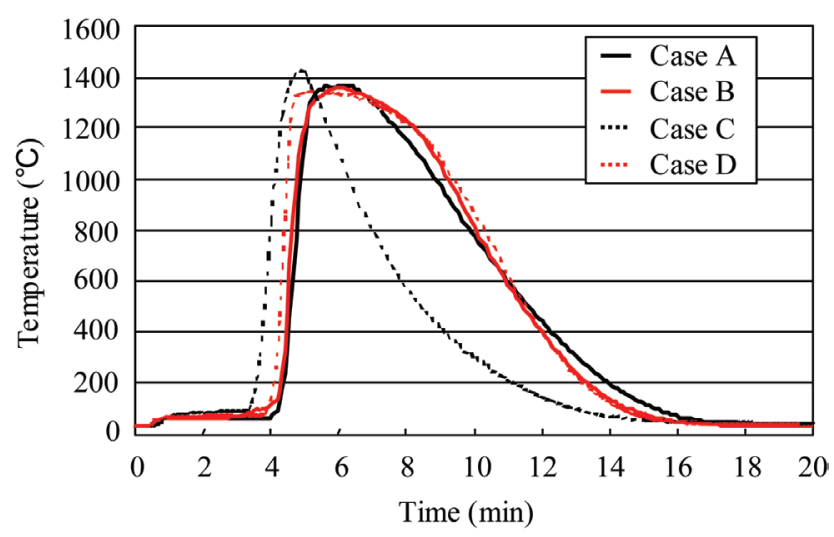

Fig. 3. Measurement result of temperature at $100 \mathrm{~mm}$ from the top surface of sintering bed.

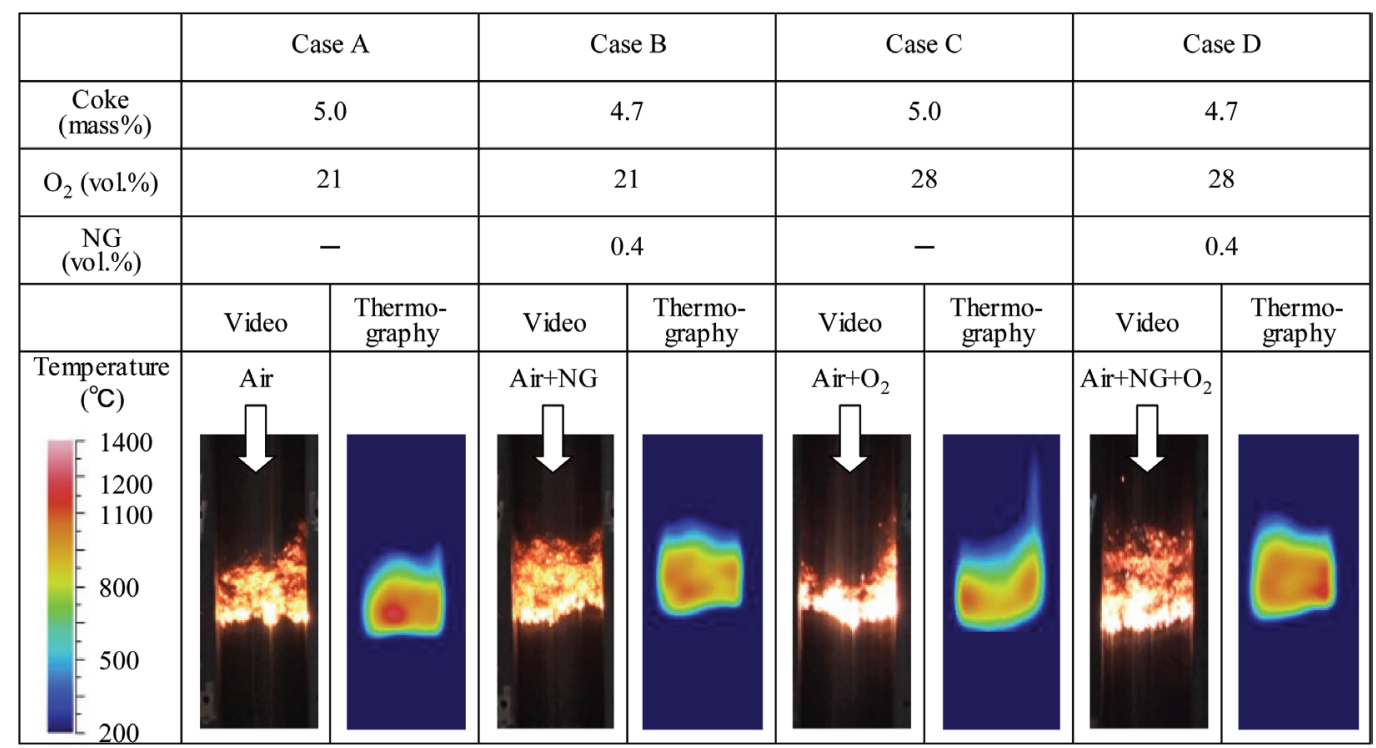

Fig. 2. Observation results of combustion behavior in the sintering bed by video camera and thermo-graphy. 
件 $\mathrm{A}$ では，下層ほど $1200^{\circ} \mathrm{C}$ 以上の保持時間が長くなってい る。条件 Cでも条件 $\mathrm{A}$ と同様の傾向を示し, $1200^{\circ} \mathrm{C}$ 以上の 保持時間が, 条件 $\mathrm{A}$ と比較して短縮している。一方, 条件 $\mathrm{B}$ では，上層部における $1200^{\circ} \mathrm{C}$ 以上の保持時間が条件 $\mathrm{A} に$ 対し，35s 延長され，下層部の $1200^{\circ} \mathrm{C}$ 以上の保持時間が $80 \mathrm{~s}$ 短縮している。条件 Dでは, 傾向は条件 B と類似している が, ベッド表面から $100 \mathrm{~mm}$ 位置における $1200^{\circ} \mathrm{C}$ 以上の保 持時間が，条件 $\mathrm{A}$ と比較して $65 \mathrm{~s}$, 条件 B と比較して, さら に30s延長している。これより，ヒートパターンに打ける， 条件 Dの $1200^{\circ} \mathrm{C}$ 以上の保持時間が条件 B と比較して延長 していることが確認できた。

\section{3 ・2 焼結鉱品質, および焼結特性に及ぼす酸素富化の影響}

Fig.5 に各実験条件に打ける焼結時間を示す。条件 A 対 し，粉コークスと NGを併用した焼成条件 Bでの焼結時間 は殆ど差が見られなかった。一方，粉コークスのみを用い て酸素富化した条件Cでは，大幅に焼結時間が短縮した。 また，粉コークスと NGを併用して用い，酸素富化した条 件Dでは，条件Cよりも焼結時間は長いが，条件 Aや条件 Bに比べて短かった。

次にFig.6に各実験条件における, 落下強度と焼結歩留 を示す。条件 Bでは落下強度, 焼結歩留ともに条件 Aより も高かった。条件Cでは, 落下強度は条件 Aよりも若干高 いが，焼結歩留は変わらなかった。また，条件 B と比較す ると，落下強度，打よび焼結步留共に低くなった。条件 D では, 条件 $\mathrm{B}$ および $\mathrm{A}$ と比較して, 落下強度, および焼結

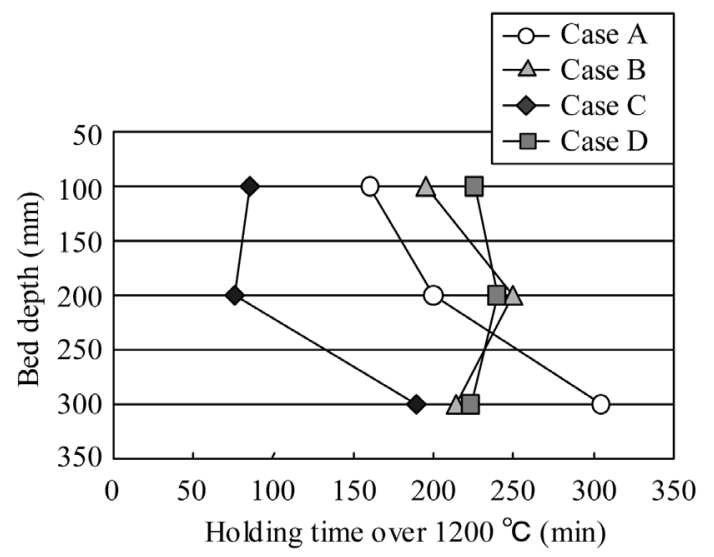

Fig. 4. Effect of various gas injection on holding time over $1200^{\circ} \mathrm{C}$.

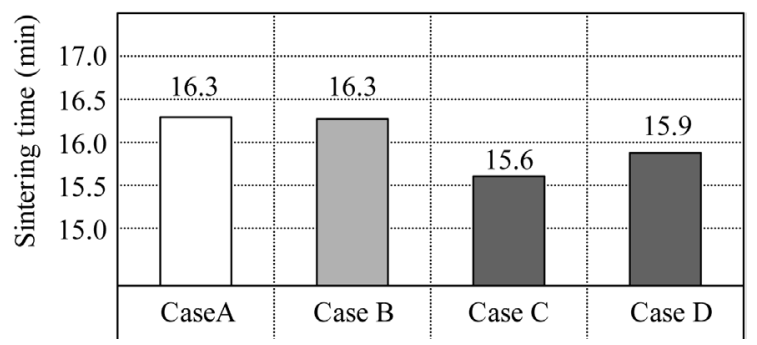

Fig. 5. Comparison of sintering time in the pot test.
歩留が共に高くなった。

\section{$3 \cdot 3$ 焼結鉱品質, および焼結特性に及ぼす酸素濃度の影響}

条件Dに打ける酸素濃度の影響を調査するため, $\mathrm{NG}$ 濃 度を $0.4 \mathrm{vol} 1 . \%$ で一定にしたまま, 吸引空気中の酸素濃度を 変更する実験を行った。Fig.7に粉コークスと NGを併用し て酸素富化を行った条件Dに打ける酸素濃度と落下強度と の関係を示す。28vol.\%までは酸素濃度の上昇に伴い, 落下 強度も向上したが，32vol.\%まで酸素濃度を上昇させた水 準では，28vol.\%と比較して，大きな差は見られなかった。 これは酸素富化による落下強度の向上効果が飽和している ことを示している。また, Fig.8に吸引空気中の酸素濃度と 焼結時間の関係を示す。酸素濃度の増加に伴い焼結時間が 短くなった。

\section{4. 考察}

\section{$4 \cdot 1$ 粉コークスとNG 併用焼成条件でのヒートパターンに及 ぼす酸素富化の影響}

$3 \cdot 1$ 節に示したように,ヒートパターンの測定結果よ り, 条件 A と比較し, 粉コークスと NGを併用し, 酸素富化

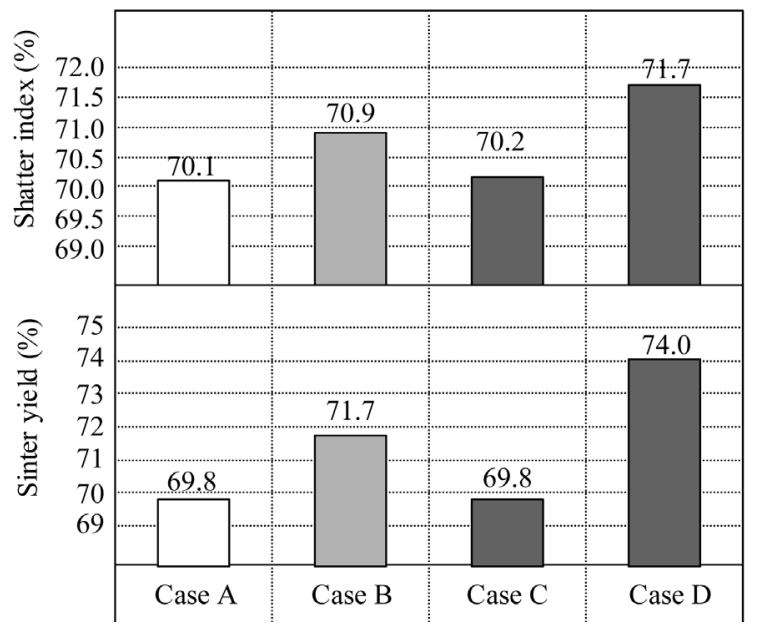

Fig. 6. Comparison of cold strength and sinter yield in the pot test.

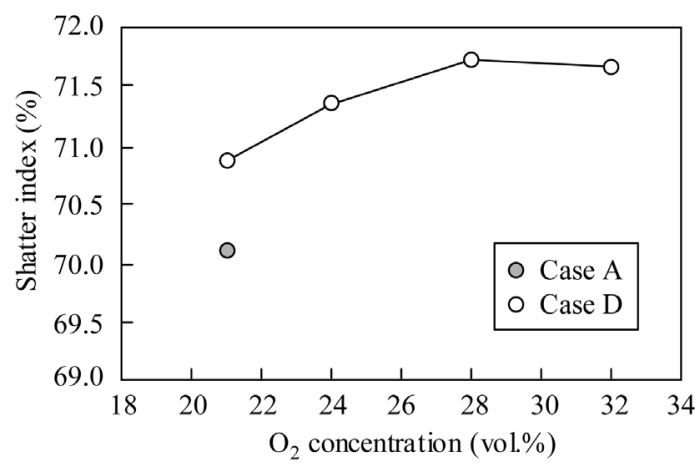

Fig. 7. Effect of $\mathrm{O}_{2}$ concentration on the sinter strength with Case D. 
を行わなかった条件 Bでは, 最高到達温度からの冷却が緩 やかになることで，高温保持時間が延長した。前報了ににも 示したように, 焼結べッド表面から吹き込まれた NGが粉 コークス燃焼帯の上方で燃焼を開始し，その加熱されたガ スが下方の赤熱帯へ吸引されるため, 条件 $\mathrm{A} よ り$ 冷却が緩 やかになると考えられる。ここで, NGの約 $90 \%$ を構成す るメタンガスの燃焼温度範囲は, 真空条件, 2 12vol.\%濃 度条件に打いて, $650 \sim 750^{\circ} \mathrm{C}$ である ${ }^{11)}$ 。

粉コークスのみを用い, 酸素富化した条件Cでは, 条件 $\mathrm{A}$ と同一の粉コークス配合率であるにもかかわらず, 急激 な温度上昇の開始時間が早かった。最高到達温度からの冷 却が急であり，また，最高到達温度も高くなった。これは， 酸素濃度の上昇による粉コークスの燃焼速度の上昇による ものと推察される。

一般的な粉コークス中の炭素 (C) の燃焼反応 $(\mathrm{C}(\mathrm{s})+$ $\left.\mathrm{O}_{2}(\mathrm{~g})=\mathrm{CO}_{2}(\mathrm{~g})\right)$ の反応速度式は, 逆反応の速度を無視 すると次式で表される ${ }^{12,13)}$ 。

$$
R_{C}^{*}=n_{C} 4 \pi r^{2} k_{C}\left[O_{2}\right]
$$

$$
R_{C}^{*}: \text { 反応速度 }(\mathrm{mol} / \mathrm{s})
$$

$k_{C}$ : 反応速度定数 $(\mathrm{m} / \mathrm{s})$

$n_{C}:$ 系中の炭素粒子の総数 $(-)$

$r$ : 炭素粒子半径 $(\mathrm{m})$

$\left[O_{2}\right]$ : 酸素濃度 $\left(\mathrm{mol} / \mathrm{m}^{3}\right)$

この式に打いて, 炭素の燃焼速度は酸素濃度の増加に比 例し速くなる。また, 反応速度定数は, 温度の影響を受け, 温度の上昇に伴って大きくなる ${ }^{14)}$ 。Hottelらは炭素単球の 粒子について燃焼速度の測定を行い，速度定数を報告して おり ${ }^{15-17)}$ ，それを Muchi and Higuchi ${ }^{18)}$ の手法に倣って次式 のように整理できる。

$$
k_{C}=6.53 \times 10^{9} \exp \left(\frac{-44000}{R T}\right) \times \sqrt{T}
$$

$R:$ 気体定数 $(\mathrm{cal} / \mathrm{K} / \mathrm{mol})$

$T:$ 温度 $(\mathrm{K})$

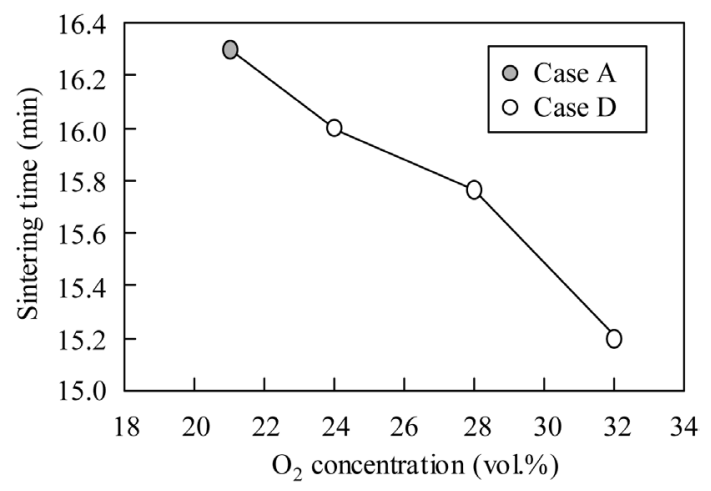

Fig. 8. Effect of $\mathrm{O}_{2}$ concentration on the sintering time with Case D.
ここで，炭素の燃焼温度は約 $800^{\circ} \mathrm{C}$ とれており，(1), (2) 式より求めた $800^{\circ} \mathrm{C}$ 付近での温度推移に伴う単位面積 あたりの燃焼速度を Fig.9に示す。 $800^{\circ} \mathrm{C}$ における単位面 積あたりの燃焼速度は, 酸素濃度 $21 \mathrm{vol} . \%$ で約 $47 \mathrm{~mol} / \mathrm{s} / \mathrm{m}^{2}$, $25 \mathrm{vol} . \%$ で約 $56 \mathrm{~mol} / \mathrm{s} / \mathrm{m}^{2}, 29 \mathrm{vol} . \%$ で約 $65 \mathrm{~mol} / \mathrm{s} / \mathrm{m}^{2}$ と増加し た。一方, 酸素濃度 $21 \mathrm{vol} . \%$, 温度 $800^{\circ} \mathrm{C}$ に打ける燃焼速度 と同等となる燃焼条件は, 酸素濃度 $25 \mathrm{vol} . \%$ では約 $790^{\circ} \mathrm{C}$, $29 \mathrm{vol} . \%$ では, 約 $780^{\circ} \mathrm{C}$ である。

したがって, 酸素濃度の上昇により, 低温から炭材の燃 焼が進行し, 燃焼速度も増加するため, ヒートパターンに おける急激な温度上昇の開始時間が早くなったものと考え られる。

$\mathrm{NG}$ は約 $90 \%$ をメンガス $\left(\mathrm{CH}_{4}\right)$ で構成されている。 一般的な炭化水素の燃焼反応速度式は, 数多くの素反応 の組み合わせで表される。例えば, メタンガス燃焼反応 $\left(\mathrm{CH}_{4}(\mathrm{~g})+2 \mathrm{O}_{2}(\mathrm{~g})=\mathrm{CO}_{2}(\mathrm{~g})+2 \mathrm{H}_{2} \mathrm{O}(\mathrm{g})\right)$ では, メタン ガスはいくつかの途中生成物 $\left(\mathrm{CH}_{3}, \mathrm{CH}_{2} \mathrm{O}, \mathrm{HCO}, \mathrm{CO}, \mathrm{H}_{2}\right.$ 等) を経て, $\mathrm{CO}_{2}$ や $\mathrm{H}_{2} \mathrm{O}$ に変化する ${ }^{19)}$ 。ここで, メタンガス の燃焼速度式は次式で表される ${ }^{11}$ 。

$$
R_{\mathrm{CH}_{4}}^{*}=k_{\mathrm{CH}_{4}}\left[\mathrm{CH}_{4}\right]^{a}\left[\mathrm{CH}_{3}\right]^{b}\left[\mathrm{CH}_{2} \mathrm{O}\right]^{C}[\mathrm{CO}]^{d}\left[\mathrm{H}_{2}\right]^{e} \cdots \cdots\left[\mathrm{O}_{2}\right]^{X}
$$

$R_{C_{4}}^{*}:$ 反応速度 $\left(\mathrm{mol} / \mathrm{s} / \mathrm{m}^{2}\right)$

$k_{\mathrm{CH}_{4}}$ : 反応速度定数 $(\mathrm{m} / \mathrm{s})$

$[i]^{l}:$ 要素 $\mathrm{i}$ の濃度 $\left(\mathrm{mol} / \mathrm{m}^{3}\right)$

$\left[\mathrm{O}_{2}\right]$ : 酸素濃度 $\left(\mathrm{mol} / \mathrm{m}^{3}\right)$

$I, X$ : 反応式における次数 (-)

この時, 反応速度定数 $k_{\mathrm{CH}_{4}}$ は, $\mathrm{k}=\mathrm{A} \exp (-\mathrm{E} / \mathrm{RT})$ で表 されるアレニウスの式に従って整理されており, 温度の関 数である。また，(3) 式において, 炭素の燃焼速度と同様に 酸素濃度の上昇に伴い燃焼速度が速くなる。

Fig.10において, 全ての条件における高さ方向での凝結 材 (コークス), $\mathrm{NG}$ の燃焼位置とヒートパターンの関係 を, 点火後に同一時間経過した状態を想定した模式図で説

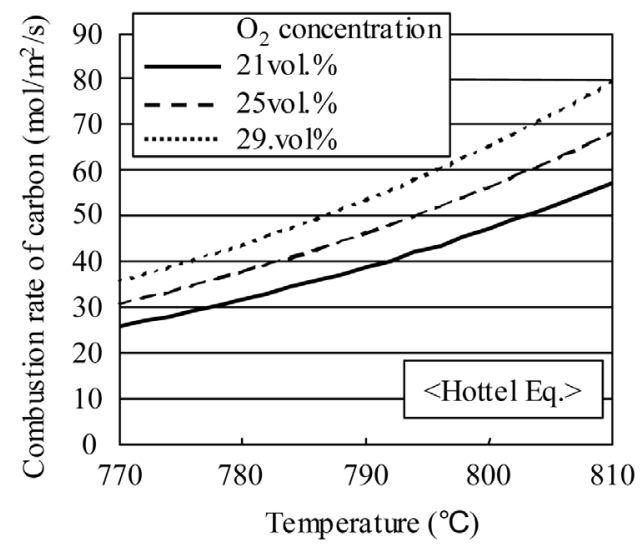

Fig. 9. Effect of temperature and $\mathrm{O}_{2}$ concentration on the combustion rate of carbon with Hottel Eq.. 
(a) Case $\mathrm{A}$

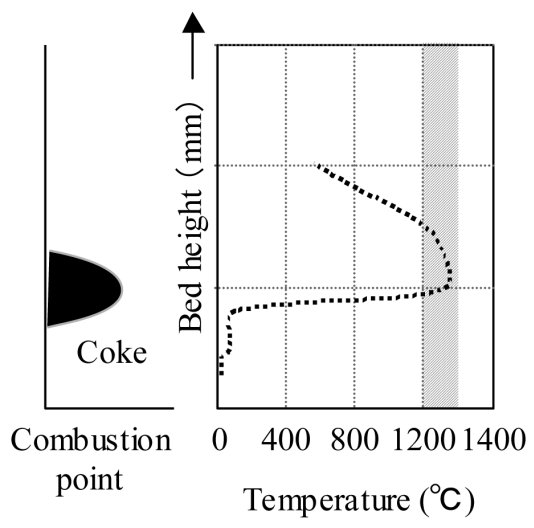

(c) Case C

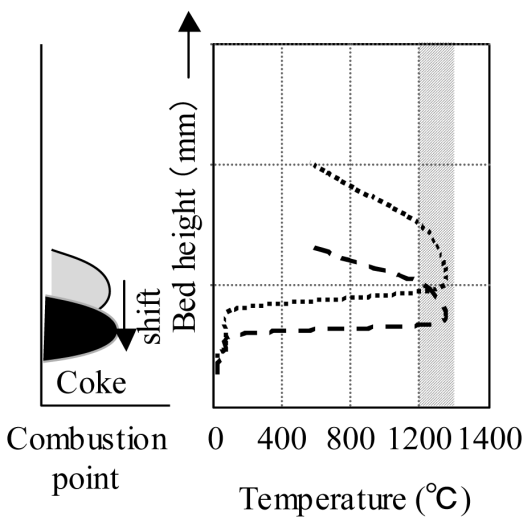

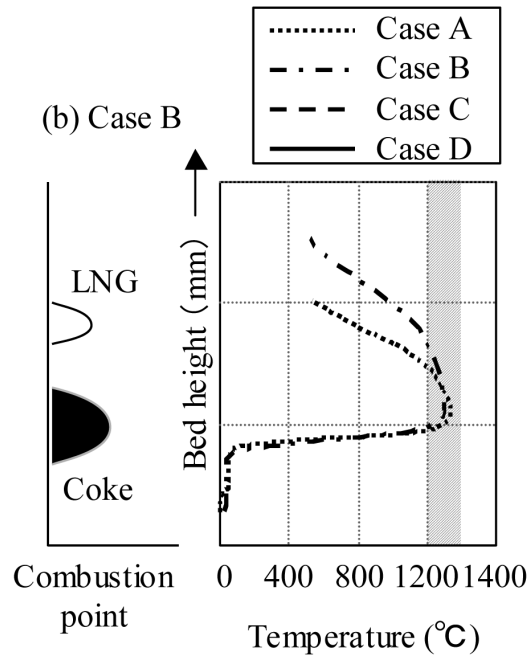

(d) Case D

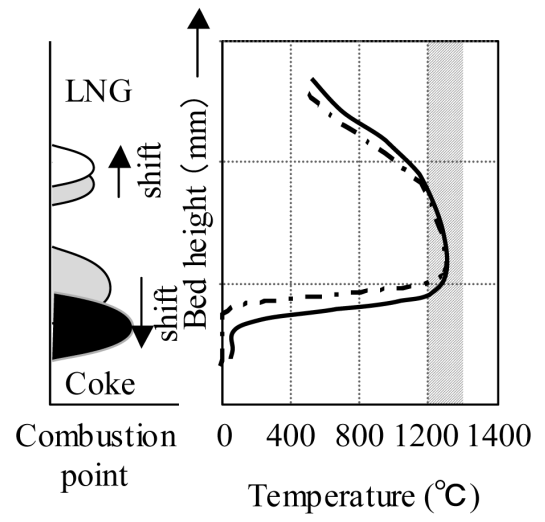

Fig. 10. Schematic diagram of heat pattern and ignition behavior with Case A, B, D.

明する。条件 Aでは, コークスの燃焼は高さ方向の比較的 狭い範囲で生じて抢り, 四中の（a）に示すようなヒートパ

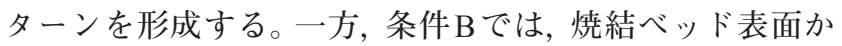

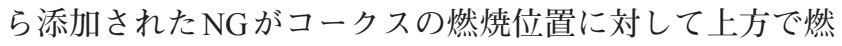
焼することで，コークスの燃焼位置に供給されるガス温度 が上昇し，コークス燃焼位置上方の焼結ベッドの冷却が緩 和され，図中の（b）に示すようなヒートパターンを形成す ると考えられる。また, 条件Cでは, 酸素濃度の上昇によ り，コークスの燃焼速度，および熱生成速度が増加するた め, 上方から流入する通過空気への対流伝熱による着熱効 率が向上する。これにより, コークスの燃焼位置は下方に 早く進行する。その結果，条件Cでは四中の (c) に示すよ うな, 条件 $\mathrm{A}$ と比較して下層へずれたヒートパターンを形 成する。条件 Dでは, 条件 C と同様に酸素富化により燃焼 位置が下層に進行する。一方, NGも同様に酸素濃度の上 昇により，燃焼速度が増加するために，焼結原料表面から 吹き込んでいる $\mathrm{NG}$ の燃焼は，より上方の低温側で生じる。 これにより，条件Dでは条件 Bよりも更にコークスおよび $\mathrm{NG}$ の燃焼位置間隔がさらに広がることで, 図中の（d）に

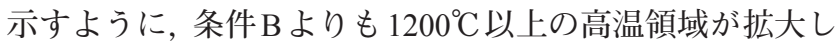

たヒートパターンを形成すると考えられる。

\section{$4 \cdot 2$ シミュレーションモデルによる検討}

ヒートパターンに及ぼす各条件の影響について，メタン ガスの燃焼を考慮に入れた数值シミュレーションモデルに よる解釈を試みた 3,20)。このモデルは, 物質量, および熱量, 運動量の保存則に基づいた基礎式によって規定されてお り，粉コークスの燃焼， $\mathrm{CaCO}_{3}$ の分解，および水の蒸発と 凝縮を焼結中の反応として考慮した。さらに, 気体燃料吹 き込及法における温度分布を計算するため, メタンガスの 燃焼を考慮した。酸素富化とメタンガスの吹き込みは境界 でのそれぞれの濃度を設定することで計算した。

まずシミュレーションモデル，およびラボ焼結鍋試験に よって得られるヒートパターンを比較した。Table 3 に示 した粉コークスと NGを併用した焼成条件 B と同様に, 粉 コークス配合比を $4.6 \mathrm{mass} \%$, NG濃度を吸引空気に対して $0.4 \mathrm{vol} . \%$ に設定し，点火後 $6 \mathrm{~min}$ 間の $\mathrm{NG}$ 添加を計算条件と して与えた。また, 粉コークスのみを用い酸素富化した条 件Cの計算条件における粉コークス配合比は $5.0 \mathrm{mass} \%$, 酸 素濃度は吸引空気に対して28vol.\%に設定した。Fig.11に 原料表面から $100 \mathrm{~mm}$ の位置でのヒートパターンについて, 
(a) Case B $\left(\mathrm{CH}_{4}: 0.4\right.$ vol. $\%, \mathrm{O}_{2}: 21$ vol.\% $)$

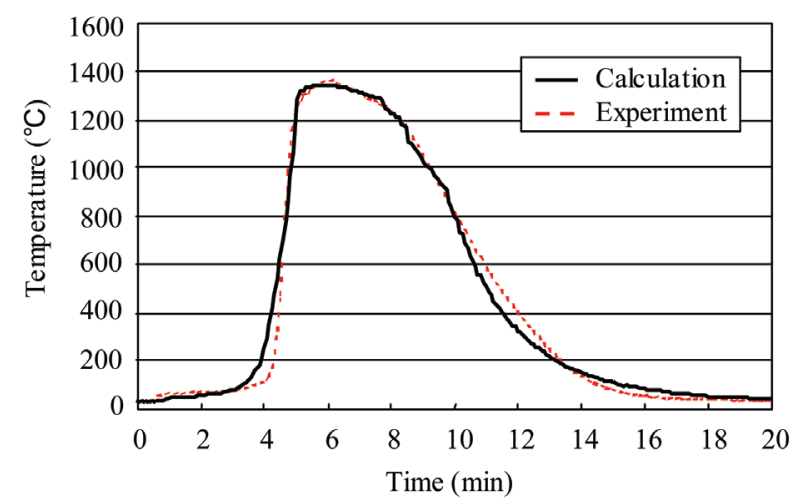

(b) Case $\mathrm{C}\left(\mathrm{CH}_{4}: 0.0\right.$ vol. \%, $\mathrm{O}_{2}: 28$ vol. \%)

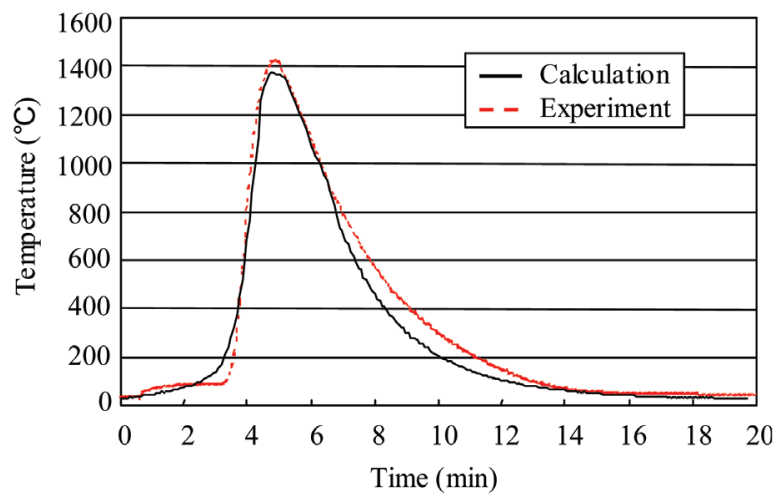

Fig. 11. Comparison of heat patterns between experimental value and calculated one at $100 \mathrm{~mm}$ from the top surface of sintering bed.

実験結果と計算結果をあわせて示す。条件 B jよび条件 C 共に, $800^{\circ} \mathrm{C}$ 以上の高温領域では, 実験結果と計算結果が良 く一致しており, 本モデルによる $1200^{\circ} \mathrm{C}$ 以上の高温領域に おけるヒートパターンについては, シミュレーションモデ ルによる解釈が概ね可能と推察した。

ここでは粉コークスとNGを併用して用い酸素富化し た条件Dにおける酸素濃度の影響を検討した。Fig.12にシ ミュレーションモデルにより, メタンガス濃度を $0.4 \mathrm{vol} . \%$ 一定とした場合について, 酸素濃度を変更した際の点火後 200sでのヒートパターンを示す。ここではベッド表面から $100 \mathrm{~mm}$ 下方までの範囲を計算対象とした。本計算における $\mathrm{NG}$ と酸素の添加は, Fig.11で設定したのと同じタイミン グで行った。計算結果では, 条件 B と比較して条件Dにお ける酸素濃度を $21 \%$ から $28 \%$ ，36\%に増加させることによ り, 粉コークスの燃焼速度が最大となる位置が $5 \mathrm{~mm}$ 程度 ずつ下方となり,さらに最大燃焼速度は $40 \mathrm{~mol} / \mathrm{Bed}-\mathrm{m}^{3} / \mathrm{s}$ 程 度ずつ大きくなった。(以下, 燃焼速度が最大となる位置を 燃焼位置と記述する。）このことにより，粉コークスの燃焼 速度の上昇により, 燃焼位置の下方への進行は速くなった と考えられる。

メタンガスの燃焼位置は, 酸素濃度の増加にかかわら ず, 変化しなかった。Fig.13に本モデルに打ける酸素富化 に伴うヒートパターンの変化の模式図を示す。図中の (a) に示すように, 粉コークスの燃焼位置の下層へのシフトに 伴い, ヒートパターン, およびメタンガスの燃焼位置も下 層へシフトする。一方, 4・1節で述べたように, $\mathrm{NG}$ の燃焼 においては酸素濃度の上昇に伴い, 燃焼速度が同等となる 温度は低下寸るため, 図中の（b）のようにメタンガスの燃 焼位置は低温側，すなわち上方側にシフトする。したがっ て, NGと粉コークスの燃焼を合わせたヒートパターンの 変化ではその位置での温度が低下するため, 燃焼位置が変 化していないと考えられる。したがって, 粉コークスの燃 焼位置のシフトがメタンガスの燃焼位置のシフトを相殺す ることで, メタンガスの燃焼位置の移動が粉コークスに比
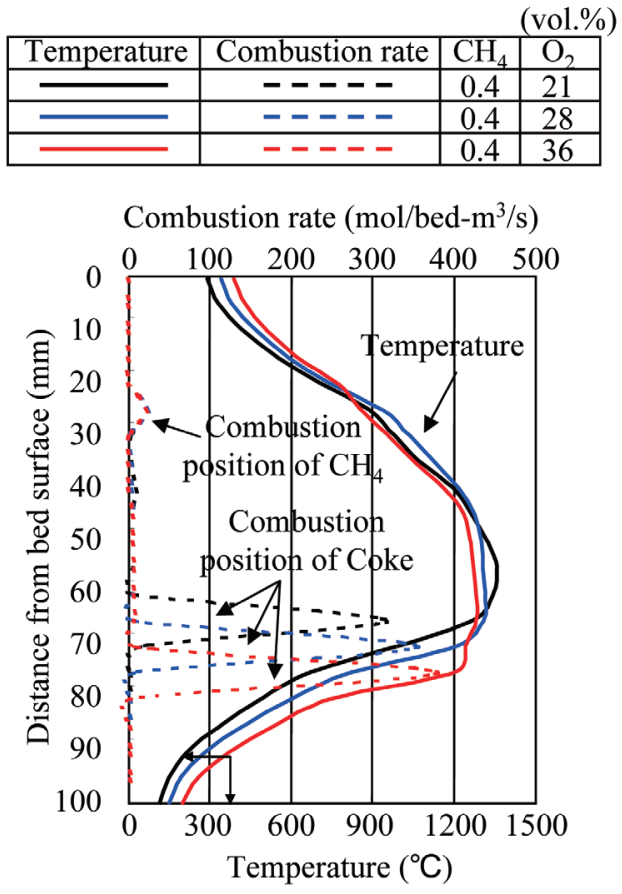

Fig. 12. Effect of the $\mathrm{O}_{2}$ concentration on the temperature distribution in the Case D with the simulation model at 200s after ignition.

べて小さくなったものと考えられる。

以上のことより, 粉コークスとメタンガスの燃焼位置の 間隔が酸素濃度の上昇に伴い大きくなる。これに伴いヒー トパターンがFig.12のように変化する。すなわち, 酸素濃 度 21 から $28 \%$ に上昇すると $1200^{\circ} \mathrm{C}$ 以上の領域が $25 \mathrm{~mm}$ ら $35 \mathrm{~mm}$ に拡大した。しかし, 酸素濃度を $36 \mathrm{vol} . \%$ まで上昇 させても, $1200^{\circ} \mathrm{C}$ 以上の領域は $35 \mathrm{~mm}$ のまま変化していな かった。これは酸素濃度が $36 \mathrm{vol} . \% の$ 条件では, 粉コーク スとメタンガスの燃焼位置の間隔が過剩に大きくなり, メ タンガスの燃焼がコークス燃焼終了後の冷却帯でのベッド 内温度の冷却速度を緩和に寄与せず, $1200^{\circ} \mathrm{C}$ 以上の領域の 拡大効果が飽和したものと推察される。 


\section{$4 \cdot 3$ 焼結特性に及ぼす酸素富化の影響}

Fig.4に示すように，負圧一定条件下での焼結実験にお いて，粉コークスのみを用い酸素富化した条件Cでは，焼 結時間が大幅に短縮し, これは前述したように, 酸素富化 により燃焼速度が上昇したことに起因していると推察さ れる。一方, 粉コークスと NGを併用して用い酸素富化し

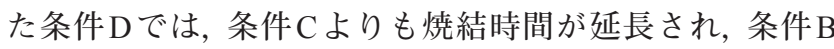
よりも焼成時間が短縮する結果となっていた。条件 Cより も条件Dに打いて焼結時間が延長した原因としては, NG と酸素の同時添加により, 高温領域が拡大し, 圧力損失が 増加したためと推察される。Fig.14に層厚を $400 \mathrm{~mm}$, 出口 側流速を $0.6 \mathrm{Nm}^{3} / \mathrm{s}$ 一定とした条件での点火後 $250 \mathrm{~s} に お け$ る条件 $\mathrm{C}$, および条件 $\mathrm{D}$ の層内温度分布と圧力分布の計算 值を示す。圧力損失が条件 Cでの $0.12 \mathrm{kPa}$ から条件 Dでは $0.33 \mathrm{kPa}$ と増加するのに伴って, 条件 $\mathrm{D}$ において $1200^{\circ} \mathrm{C}$ 以 上の高温領域が $15 \mathrm{~mm}$ から $35 \mathrm{~mm}$ へと拡大した。層全体で の圧力損失は条件 Cが $2.06 \mathrm{kPa}$ ，条件 Dが $2.23 \mathrm{kPa}$ となって おり，高温領域における圧力損失の差が，焼結層全体での 圧力損失の差に表れている。一方，吸引風量一定の条件で は, ヒートパターンにおける温度の急上昇位置に大きな差 は表れなかった。ここでは，ヒートパターンに㧫温度
の急上昇位置を Frame Front：FFと呼ぶことにする。添加 した NGの濃度は $0.4 \mathrm{vol} \%$ と非常に小さく, 酸素濃度の低 下も最大で $0.8 \mathrm{vol} . \%$ 程度であった。それゆえ燃焼性に大き な差は表れず，FFに大きな差が表れなかったものと考えら れる。したがって，吸引負圧一定条件において条件 Cより も条件 Dにおいて焼結時間が長くなったのは, 高温領域の 拡大による圧力損失の増加が主要因と考えられる。

条件 $\mathrm{B} よ り も$ 条件 $\mathrm{D}$ において, $1200^{\circ} \mathrm{C}$ 以上の高温領域が より大きいにもかかわらず，焼結時間が短縮していた原 因としては, 高温領域の拡大による圧力損失増加の効果 よりも, 前述した酸素富化による粉コークスの燃焼性向上 による効果が大きいことが推察される。Fig.15にFig.14で 示した条件での条件 $\mathrm{B}$ ，および条件 $\mathrm{D}$ の層内温度分布と圧 力分布の計算值を示す。条件 $\mathrm{B}$ と比較して条件 Dに打いて $1200^{\circ} \mathrm{C}$ 以上の高温領域が $25 \mathrm{~mm}$ から $35 \mathrm{~mm}$ へと拡大してお り, 高温領域に打ける圧力損失が条件 Cでは $0.23 \mathrm{kPa}$, 条件 $\mathrm{D}$ では $0.33 \mathrm{kPa}$ と増加した。また, 条件 Dでは, 酸素富化に よる燃焼性の向上に伴う，ヒートパターンにおける温度の 急上昇位置降下速度 (Frame Front Speed : FFS) の増加が顕 著に表れており, FF は条件 $\mathrm{B}$ と比較して, 条件 Dが $15 \mathrm{~mm}$ 下方に進行していた。したがって, 吸引負圧一定の計算条

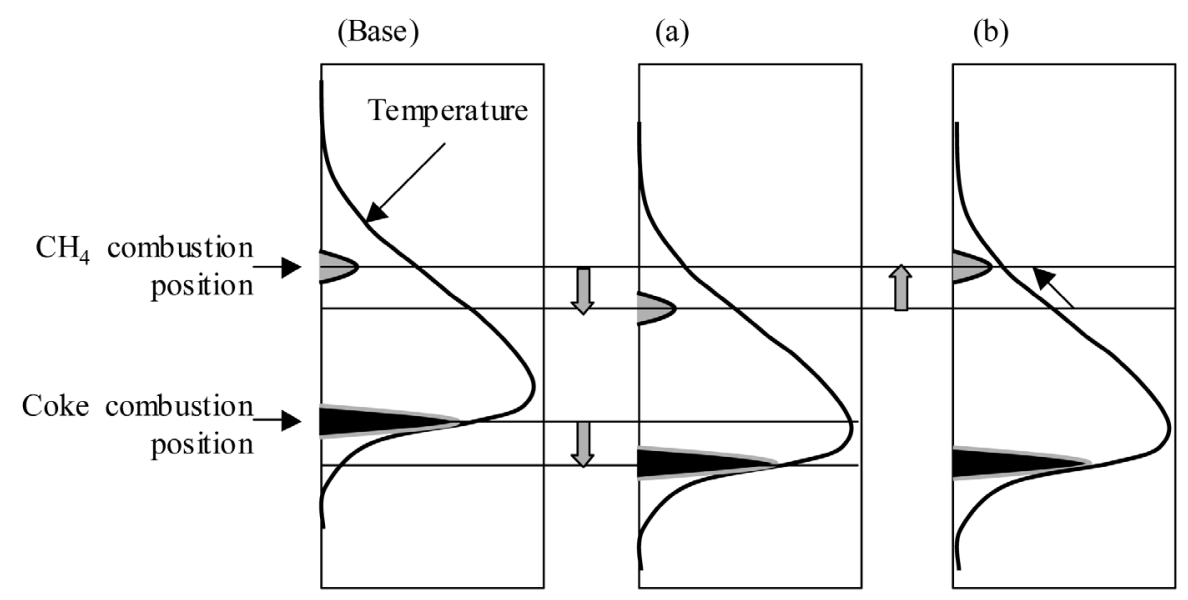

Fig. 13. Schematic diagram of heat pattern change with $\mathrm{O}_{2}$ enrichment in the simulation model.

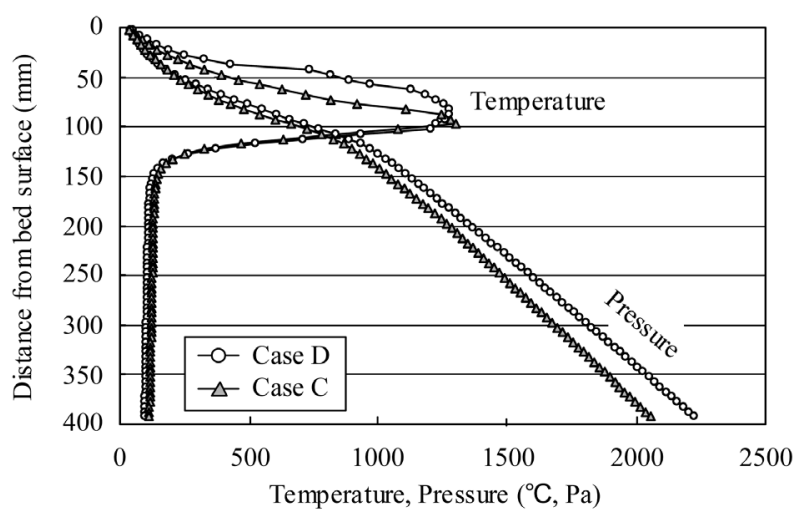

Fig. 14. Temperature distribution and pressure drop in the bed for Case $\mathrm{C}$ and $\mathrm{D}$ with simulation model.

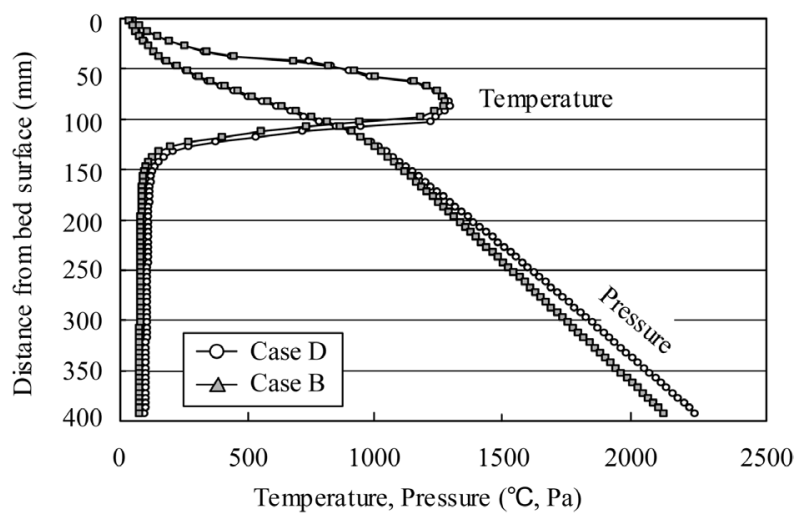

Fig. 15. Temperature distribution and pressure drop in the bed for Case B and D with simulation model. 
件において, 条件 Bよりも条件 DのFFSが大きく, 焼結時 間が短いことから, 圧力損失の影響を加味しても, 酸素富 化による粉コークスの燃焼性向上に伴う FFS の増加効果が 大きいと考えられる。

Fig.6に示すように, 落下強度・焼結歩留に関しては両值 とも, 条件 $\mathrm{A}$ と比較し, 条件 Bが高く, さらに条件 B と比較 して条件Dが高かった。これは, Fig.4に示すように, 上層 部での高温保持時間が条件 Aでは $160 \mathrm{~s}$, 条件 Bでは 195s, 条件 Dでは $225 \mathrm{~s}$ と, 延長したためと推察される。焼結反応 では, 約 $1200^{\circ} \mathrm{C}$ で融液が生成を開始するため, $1200^{\circ} \mathrm{C}$ 以 上での高温保持時間が実質的な焼結反応時間となってお $り^{21)}$, 条件Dでは, 条件 Bよりも焼結反応が進行したため に落下強度・焼結歩留が向上したものと推察される。一方, Fig.6にも示したように条件Cでは, 条件Bよりも強度が低 下していた。これは表層から $100 \mathrm{~mm}, 200 \mathrm{~mm}$ の熱電対にお ける高温保持時間がそれぞれ110s，175s 低下いることから も，焼結反応時間が短くなったためであると考えられる。 条件Cでは条件 A と比較して, 高温保持時間が短くなった にもかかわらず, Ishimitsuらの実験結果 ${ }^{22)}$ と同様に, 落下 強度, 焼結歩留に変化は無かった。

Fig.16に各実験条件における, 生産率と落下強度の関係 を示す。ここで, 生産率は焼結鉱の正味重量を試験鍋の断 面積，および焼結時間で除して計算した。条件 D と条件 $\mathrm{B}$ を比較した場合, 条件Dでは高温保持時間が延長し, 焼結 時間が短縮されたために, 生産率, および泠間強度が向上 した。一方, 条件 Dと条件 Cを比較した場合, 高温保持時 間は大幅に延長されたために, 冷間強度は大幅に向上し, 若干の焼結時間の延長が見られるが, 冷間強度の向上に伴 う歩留の向上により, 生産率も向上している。条件 B，打よ び条件Cに打ける生産率と冷間強度の向上効果を, 単純に 合算した場合と比べて, 条件Dでは落下強度と生産率が向 上しており，これは $\mathrm{NG}$ と酸素を同時に使用することによ る, いわゆる相乗効果によるものである。

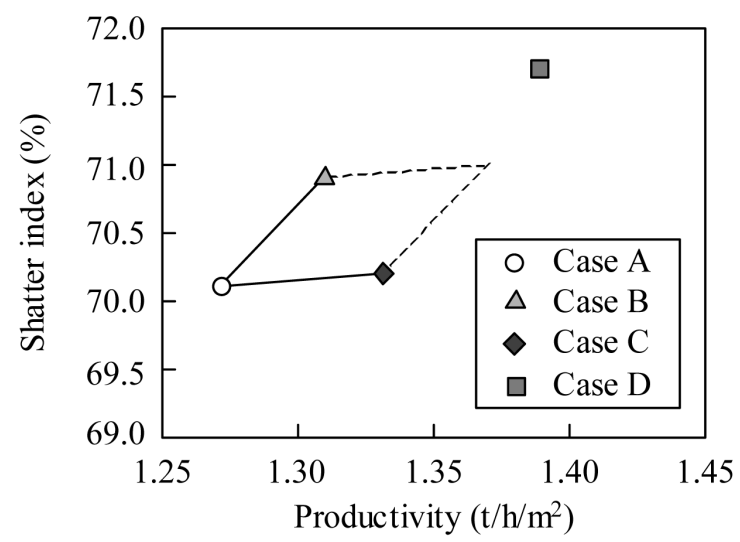

Fig. 16. Relationship between productivity and cold strength in pot test.

\section{5. 結言}

（1）気体燃料と酸素を併用して添加することによって, 焼結鉱の冷間強度が大幅に向上した。これは, 焼結時の $1200^{\circ} \mathrm{C}$ 以上の保持時間が延長しており，焼結反応が促進さ れたためと考えられる。

(2) 保持時間の延長は, 酸素濃度の上昇に伴い, 粉コー クスと気体燃料の燃焼位置の間隔が大きくなることによる ものと考えられる。

（3）粉コークスと NG0.4vol\%を併用し, 酸素富化した焼 成条件に扔いて, 酸素濃度が $32 \mathrm{vol}$ \% まで上昇させた条件 では, 落下強度の向上効果が飽和した。これは, 凝結材と $\mathrm{NG}$ の燃焼位置間隔が拡大しすぎることによって, NGの燃 焼が $1200^{\circ} \mathrm{C}$ 以上の領域の拡大に寄与しなくなったためと 考えられる。

（4）粉コークスと NGを併用し, 酸素富化した焼成条件 では, NG 添加の効果, 酸素富化の効果を単純に合算した ものよりも NGと酸素を同時使用することによる相乗効果 によって, 落下強度と生産率がより向上している。

\section{文献}

1 ) M.Sasaki and Y.Hida: Tetsu-to-Hagané, 68(1982), 563.

2 ) T.Inazumi, K.Shinada and M.Kawabe: Tetsu-to-Hagané, 68(1982), 2207.

3 ) N.Oyama, Y.Iwami, T.Yamamoto, S.Machida, T.Higuchi, H.Sato, M.Sato, K.Takeda, Y.Watanabe, M.Shimizu and K.Nishioka: ISIJ Int., 51(2011), 913.

4 ) M.Sugawara, T.Koitabashi, T.Hamada, K.Okabe, M.Saino, Y.Sato: Kawasaki Steel Giho, 5(1973), No.1, 30.

5 ) F.Cappel and H.Weisel: Proc. Ironmaking Conf. Proc., 51(1992), 73.

6 ) H.Noda, N.Sakamoto, K.Ichikawa, S.Machida and S.Rokugawa: Tetsu-to-Hagané, 87(2001), 305.

7 ) H.Kang, S.Choi, W.Yang and B.Cho: ISIJ Int., 51(2011), 1065.

8 ) B.Lewis and G.Von Eibe: Combustion, Flame and Explosions of Gases, Academic Press, New York \& London, (1961), 692.

9 ) N.Mori: Shinban Enerugi Kanri Gizyutsu, Center of Energy Saving. Inc, Tokyo, (1989), 285.

10) I.Nakamachi and F.Shoji: Gasu Nensho no Riron to Jissai, Center of Energy Saving. Inc, Tokyo, (2000), 5.

11) M.Hasatani, J.Kimura, N.Arai and A.Sato: Nensho no Kiso to Oyo, Kyoritsu-shuppan-sha, Tokyo, (1986), 22.

12) E.Kasai, H.Taketomi and Y.Omori: Bull. Res. Inst. Miner. Dressin. Metall., 40(1984), 61.

13) H.Taketomi, E.Kasai and Y.Omori: Tetsu-to-Hagané, 69(1983), S723.

14) E.Kasai and Y.Omori: Tetsu-to-Hagané, 72(1986), 1537.

15) C.M.Tu, H.Davis and H.C.Hottel: Ind. Eng. Chem., 26(1934), 749.

16) H.Davis and H.C.Hottel: Ind. Eng. Chem., 26(1934), 889.

17) A.Parker and H.C.Hottel: Ind. Eng. Chem., 28(1936), 1334.

18) I.Muchi and J.Higuchi: Tetsu-to-Hagané, 56(1970), 371.

19) T.Takagi, K.Nanbu, Y.Matsumoto and S.Kamiyama: Suchi-RyutaiRikigaku series 5 Nensho-Kihakuryu-Konsoryu-Denziryutai-noKaiseki, Tokyo-Daigaku-Shuppan-sha, Tokyo, (1995), 6.

20) K.Nishioka, T.Maeda, K.Ono, M.Shimizu, Y.Iwami, N.Oyama, M.Sato and K.Takeda: CAMP-ISIJ, 22(2009), 840, CD-ROM.

21) T.Inazumi: Tekko-Gizyutsu- no-Nagare 1 Shoketsuko, ISIJ, Tokyo, (2000), 138.

22) A.Ishimitsu, S.Wakayama, S.Tomura and K.Sato: Tetsu-to-Hagané, 49(1963), 342. 